\title{
LITERATURA, DIREITO E SOCIOLOGIA DAS RELAÇÕES RACIAIS NO ROMANCE “OS TAMBORES DE SÃO LUÍS”
}

\author{
Paulo Fernando Soares Pereira ${ }^{1}$
}

\begin{abstract}
Resumo: $\mathrm{O}$ artigo tem como objetivo analisar como se apresentam as relações raciais no romance "Os Tambores de São Luís: a saga do negro brasileiro", do escritor Josué Montello, relacionando o discurso das personagens, predominantemente negras, com as posições de parcela da literatura que discute relações raciais, principalmente a partir do pensamento de Frantz Fanon. A razão de escolha desse recorte se deve à profundidade das informações históricas e sociológicas contidas no texto do livro, o qual elegeu a luta contra a escravidão negra como o centro do protagonismo da narrativa. Nesse contexto, as vozes das personagens serão confrontadas com a parcela escolhida da literatura que trata das relações raciais. Sistematizamos o texto em três momentos, os quais correspondem aos períodos temporais compreendidos no romance: a) o colonialismo que se instala: os quilombos como locais de fala e de resistência dos sujeitos; b) o colonialismo que se consolida: a vida urbana e os dilemas do racismo e; c) o colonialismo que perdura: a abolição e a não inclusão da população negra na emergente República. Como resultado, apresenta a relevância do protagonismo de personagens negros na literatura como sujeitos que lutam pela efetividade de seus direitos e como construtores de suas histórias. A metodologia consistiu na revisão crítica de literatura.
\end{abstract}

Palavras-chave: Literatura; Diáspora; Liberdade; Quilombo; Direito.

\section{LITERATURE, LAW AND SOCIOLOGY OF RACE RELATIONS IN THE NOVEL "THE DRUMS OF SÃO LUÍS"}

\begin{abstract}
The article aims to analyze how race relations are presented in the novel "The Drums of São Luís: the saga of the black Brazilian", by the author Josué Montello. The article links the (predominantly black) characters' discourse, with the stances held by part of the literature that discusses racial relationships, mainly after the work of Frantz Fanon. The reason for choosing this perspective is due to the depth of the historical and sociological investigation contained in the book, which picked the fight against black slavery as the story's protagonist. In this context, the characters' voices are confronted

\footnotetext{
${ }^{1}$ Doutor em Direito, Estado e Constituição pela Universidade de Brasília - UnB. Mestre em Direito e Instituições do Sistema de Justiça pela Universidade Federal do Maranhão - UFMA. Integrante da Advocacia-Geral da União - AGU (Procurador Federal), atuando em causas envolvendo povos indígenas, comunidades quilombolas e patrimônio cultural brasileiro. E-mail: paulofsp1983@gmail.com ; ORCID: http://orcid.org/0000-0001-6802-9035
} 
with a specific part of the literature that deals with race relations. The article was systematized in three parts, which correspond to the timelines that appear in the novel: a) the colonialism that settles in: the quilombos as places of individual freedom of speech and resistance; b) colonialism that consolidates itself: urban life and the dilemmas of racism and; c) colonialism that remains: the abolition and non-inclusion of black people in the emerging Republic. As a result, it presents the relevance of black characters' protagonism in literature as individuals who fight for the fulfillment of their rights and as builders of their own personal life-story. The methodology used was a critical review of literature.

Keywords: Literature; Diaspora; Freedom; Quilombo; Rights.

\section{LITERATURA, DERECHO Y SOCIOLOGÍA DE LAS RELACIONES RACIALES EN LO ROMANCE "LOS TAMBORES DE SÃO LUÍS"}

Resumen: El artículo tiene como objetivo analizar cómo se presentan las relaciones raciales en el libro "Os Tambores de São Luís: la saga del negro brasileño", del escritor Josué Montello, relacionando el discurso de los personajes, predominantemente negros, con las posiciones de parte de la literatura que discute las relaciones raciales, principalmente del pensamiento de Frantz Fanon. La razón para elegir este recorte se debe a la profundidad de la información histórica y sociológica contenida en el texto del libro, que eligió la lucha contra la esclavitud negra como el centro del protagonismo de la narración. En este contexto, las voces de los personajes se enfrentarán con la parte elegida de la literatura que se ocupa de las relaciones raciales. El texto se sistematizó en tres momentos, que corresponden a los períodos temporales de la novela: a) el colonialismo que se instala en: los quilombos como lugares de expresión y resistencia de los sujetos; b) la consolidación del colonialismo: la vida urbana y los dilemas del racismo y; c) el colonialismo que perdura: la abolición y la no inclusión de la población negra en la República emergente. Como resultado, presenta la relevancia del protagonismo de los personajes negros en la literatura como sujetos que luchan por la efectividad de sus derechos y como constructores de sus historias. La metodología consistió en una revisión crítica de la literatura.

Palabras clave: Literatura; Diáspora; Libertad; Quilombo; Derecho.

\section{LITTÉRATURE, DROIT ET SOCIOLOGIE DES RELATIONS INTERRACIALES DANS LE ROMAN "LES TAMBOURS NOIRS"}

Résumé: Cet article a pour but d'analyser comment les relations interraciales se présentent dans le roman "Les tambours noirs: la saga du nègre brésilien", de Josué Montello, en reliant le discours des personnages, principalement noirs, aux positions prises par Frantz Fanon dans sa littérature. Ce choix est dû à la richesse et à l'exactitude des informations historiques et sociologiques présentents dans le livre, qui fait de la lutte contre l'esclavage noir le cœur du récit. Dans ce contexte, les voix des personnages sont confrontées aux idées traitant des relations interraciales de Josué Montello. Le texte a été analysé selon trois étapes correspondants aux différentes périodes de temps présentées dans le roman: premièrement, le colonialisme qui s'installe; les quilombos comme figure symbolique de la place de la parole et de la résistance des personnes; ensuite, le colonialisme qui se consolide: la vie urbaine et les dilemmes du racisme et enfin le 
colonialisme qui perdure: l'abolition et la non-inclusion de la population noire à la République. C'est ainsi que l'article propose dans la littérature, une restitution du personnage noir comme acteur principal de la lutte pour ses droits et comme acteur central, bâtisseur de son histoire. La méthodologie utilisée pour l'écriture de cet article a été la revue critique de la littérature.

Mots-clés: Littérature; Diaspora; Liberté; Quilombo; Droit.

\section{INTRODUÇÃO: A SOCIOLOGIA DAS RELAÇÕES RACIAIS NO ROMANCE "OS TAMBORES DE SÃO LUÍS"}

A partir da Literatura, pode-se ter uma compreensão de como determinadas relações sociais são regidas pelo Direito em dado momento histórico. Por outro lado, de acordo com Enrique Dussel (2014), os sujeitos que produzem um discurso o efetuam a partir de suas posições sociais, de seu lugar sócio-histórico enquanto sujeito de enunciação de um discurso. Assim, partir de um autor branco ${ }^{2}$, de tradição hegemônica, buscou-se fazer a relação entre as relações sociais/raciais apresentadas pelo romance e a literatura que trata da sociologia das relações raciais. Pontue-se que essa tradição de literatura hegemônica pouca atenção deu a personagens negros ou a luta da própria população negra por seus direitos o que evidencia o racismo cultural entre nós.

Não se esqueça, no próprio Maranhão, a escrita de Maria Firmina dos Reis contra a escravidão, no romance Úrsula (2017). No entanto, a autora, assim como Carolina Maria de Jesus, foi bastante invisibilizada, tendo sido objeto de resgate em tempos mais recentes a partir do protagonismo da Literatura Negra, movimento em franca expansão e uma das vertentes mais criativas da nossa Literatura atualmente, a qual tem liderança capitaneada por escritoras como Conceição Evaristo que, inclusive, recentemente, foi rejeitada pelo corporativismo brancocêntrico da Academia Brasileira de Letras - ABL, em que pese a forte mobilização popular para que tal instituição tivesse uma mulher negra entre seus integrantes.

Ademais, romances diaspóricos como O quarto século, do martinicano Édouard Glissant (1986) ou Changó, el gran putas, do colombiano Manuel Zapata Olivella (2010),

\footnotetext{
${ }^{2}$ Josué Montello, além de membro, foi presidente da Academia Brasileira de Letras, Diretor da Biblioteca Nacional, Museu da República e Museu Histórico Nacional, dentre outras posições hegemônicas de destaque.
} 
tradicionalmente, foram objeto de escrita de autores negros, engajados nas lutas por direitos raciais igualitários.

Já o romance Os Tambores de São Luís é considerado um romance regionalista (BELFORT, 2013; SOUSA, 2015) e tem como protagonista Damião, homem negro, que vivia, inicialmente, em um quilombo no interior da Província do Maranhão. O livro narra vários momentos da vida de Damião, em narrativa que acompanha a luta da população negra contra a escravidão e os efeitos do racismo. O caráter denunciante do racismo estrutural, com as suas variantes, é a tônica do livro, apesar de o escritor não ter explicitado tal preocupação. Em certo momento da narrativa, um dos personagens faz um apanhado da questão e dá como exemplo do racismo brasileiro o caso do poeta Gonçalves Dias. Veja-se a fala do dr. Eduardo Olímpio Machado, personagem branco, Presidente da Província do Maranhão:

- É ainda o caso da Ana Amélia Ferreira Vale. Vossa Reverendíssima sabe de tudo, não? Pensei que já soubesse. O nosso Gonçalves Dias, amigo íntimo do dr. Teófilo Leal, apaixonou-se por uma cunhada deste, a Ana Amélia, e a pediu em casamento à dona Lourença Vale, mãe da moça, e que Vossa Reverendíssima também conhece. O Gonçalves Dias não é um homem qualquer - é o maior poeta do Brasil e amigo pessoal do Imperador. O Maranhão não tem glória mais alta. Pois nada disso teve o menor significado para a nossa dona Lourença diante deste fato, de que o Gonçalves Dias não tem culpa: - ser ele mestiço e filho bastardo. [...] O pai da Ana Amélia, instigado por dona Lourença, foi ao cartório do Raimundo Belo e deserdou a filha, sob a alegação de que a moça tinha casado com neto da negra Eméria, antiga escrava do coronel Antônio Furtado de Mendonça. [...]

E nisto voltou a ouvir a voz cheia do dr. Olímpio Machado:

- O resto do Brasil - fique Vossa Reverendíssima sabendo, para sua orientação como bispo da diocese - não leva a palma o Maranhão, em matéria de preconceito de cor. Ou se é branco, e tem todas as graças e regalias, ou não se é, e tem todas as desgraças. Pode-se ser o maior poeta do Brasil, bacharel em Coimbra, membro do Instituto Histórico e amigo pessoal do Imperador, como o nosso Gonçalves Dias, e isso não vale coisa alguma, aqui no Maranhão, se o pobre de Cristo nasceu mestiço. Vossa Reverendíssima não faz uma ideia da quantidade de cartas anônimas que recebo diariamente no palácio, pretendendo me abrir os olhos quanto ao dr. Beltrano ou a dona Beltrana - que têm negros no sangue (MONTELLO, 2005, p. 157 e 161-162).

A passagem acima é um dos vários momentos nos quais a narrativa procura relembrar a existência do racismo no Brasil, em especial na Província do Maranhão. Se, àquela época, um sujeito com o reconhecimento de Gonçalves Dias, um dos nossos maiores escritores, não escapava do ódio racial, o que dizer dos escravizados que não tinham reconhecimento algum? 
Portanto, o romance Os Tambores de São Luís possui uma narrativa permeada por elementos históricos, os quais, para os fins deste artigo, foram sistematizados em três momentos da vida do protagonista: a) O colonialismo que se instala, com o início da narrativa e a vida no quilombo, subjugado pelas forças opressoras da Colônia; b) O colonialismo que se consolida, o meio da narrativa, com a vida na fazenda e, posteriormente, na cidade, quando Damião vai para São Luís tentar o sacerdócio e enfrenta os dilemas do racismo e, por exemplo, mesmo sendo o mais qualificado do seminário, não lhe é permitido usar a batina; c) $\mathrm{O}$ colonialismo que perdura: o momento da tomada de consciência do protagonista, o qual resolve lutar contra a escravização e sofrer as consequências raciais de sua luta, deparando-se com o problema da não inclusão população negra em uma República que emergia, antes e depois da abolição de 1888.

\section{O COLONIALISMO QUE SE INSTALA E A RESISTÊNCIA QUILOMBOLA}

Discussões mais recentes sobre os quilombos têm sustentado a hipótese de tratálos como um personagem coletivo, como o primeiro intelectual negro, isto é, como uma inteligência historicamente coletiva, a mais longeva da historicidade brasileira (SIQUEIRA, 2018). Isso demonstra que há um campo não só social, político e jurídico, mas, também, acadêmico a ser explorado.

Os quilombos e mocambos constituíram-se como um direito não formal de resistência ao sistema social e jurídico que regulava a escravidão. Através deles, os sujeitos negros, que estavam de fora da "zona do ser" (CARNEIRO, 2005), eis que considerados como mercadorias, resistiam ao sistema colonial formando comunidades constituídas por escravizados que fugiam da escravidão e eram duramente reprimidas pelo Estado e pelos senhores de escravizados.

Ao tratar sobre a temática do ser, Frantz Fanon (2008) argumenta que há uma zona de não-ser, uma região extraordinariamente estéril e árida, uma rampa essencialmente despojada, onde um autêntico ressurgimento pode acontecer; todavia, a maioria dos negros não desfruta do benefício de realizar esta descida aos verdadeiros infernos.

Não parece haver dúvidas de que os mocambos e quilombos, nos termos da escrita proposta, podem ser considerados com essa zona tratada por Frantz Fanon. No caso, o romance Os Tambores de São Luís inicia com a história de um quilombo, 
prestigiando uma narrativa que mostra como se davam as relações quilombolas e mocambeiras. É bem verdade que, conquanto o romance tenha privilegiado a luta do povo negro contra a escravidão e os efeitos do racismo na sociedade brasileira, a partir de exemplo da Província do Maranhão, a parte referente ao quilombo é apenas um pequeno elemento do romance, mas bastante significativo.

Por mais que tenham passado por um processo de silenciamento, os quilombos costumeiramente estiveram a estimular o imaginário nacional, por conta de seus constantes registros na literatura, pintura, músicas etc. Esses registros demonstram que os quilombos, no passado, eram não só combatidos, mas, também, temidos, pois impunham temor à parcela da sociedade envolvente, como registram a literatura, a exemplos de romances como O Mulato, de Aluísio Azevedo (2013), ou Os Tambores de São Luís: a saga do negro brasileiro, de Josué Montello (2005). Tais relatos são importantes para se entender o processo de ressignificação e ressemantização pelo qual passaram os quilombos. Em $O$ Mulato, publicado em 1881, Aluísio Azevedo faz algumas referências à existência de quilombos na Província do Maranhão, demonstrando que eles eram temidos pela sociedade local:

Partiu. A viagem correu-lhe estúpida, como de costume naquele tempo, em que o Maranhão ainda não tinha vapores. Demais, a sua fazenda era longe, muito dentro, a cinco léguas da vila. Urgia, por conseguinte, demorar-se aí algumas horas antes de internar-se no mato; comer, beber, tratar dos animais; arranjar condução e fazer a matalotagem. Os poucos familiarizados com tais caminhos tomam sempre, por precaução, um pajem; é este o nome que ali romanticamente se dá ao guia; e o pajem menos serve para guiar o viajante, que a estrada é boa, do que parar lhe afugentar o terror dos mocambos, das onças e cobras de que falam com assombro os moradores do lugar. Não é tão infundado aquele terror: o sertão da província está cheio de mocambeiros, onde vivem os escravos fugidos com suas mulheres e seus filhos, formando uma grande família de malfeitores. Esses desgraçados, quando não podem ou não querem viver da caça, que é por lá muito abundante e de fácil venda na vila, lançam-se à rapinagem e atacam na estrada os viajantes; travando-se, às vezes, entre uns e outros, verdadeiras guerrilhas, em que ficam por terra muitas vítimas" [...]

- São escravas fugidas? Indagou Raimundo. O Cancela respondeu que não. $\underline{\text { Os }}$ mocambeiros formavam grupo à parte; nunca apareciam publicamente e viviam escondidos nos seus quilombos e só se mostravam na estrada real para atacar os viajantes. Os agregados eram pretos forros, forros em geral com a morte de seus senhores, e que habituados desde pequenos ao cativeiro, não tendo já quem os obrigasse a trabalhar e não querendo sair do sertão, ficavam por aí ao Deus dará, pedinchando pelas fazendas um bocado de arroz para matar a fome, e um pedaço de chão coberto para dormir. Simples vagabundos, que não faziam mal a ninguém" (AZEVEDO, 2013, p. 61-192, grifo nosso). 
A partir disso, ainda que $O$ Mulato aborde a questão do racismo na sociedade maranhense, em especial, não deixa de expressar uma visão negativa dos quilombos como perspectiva autoral que reflete a visão e o olhar de privilégios daqueles que os descreviam, mas, ademais, corresponde à consequência decorrente do poder de nomeação imposto pelo Direito sobre os mesmos à época, como aconteceu após a resposta do Conselho Ultramarino, que os definia como "toda habitação de negros fugidos, que passem de cinco, em parte despovoada, ainda que não tenham ranchos levantados e nem se achem pilões nele".

Já Os Tambores de São Luís: a saga do negro brasileiro, publicado em 1975, apresenta uma visão ressignificada dos quilombos e inicia a narrativa com a história de um quilombo, prestigiando a descrição das relações mocambeira e quilombolas. Assim, considera-se importante que um quilombo apareça como um lugar representativo de uma narração literária, pois o regaste da memória quilombola constitui uma forma de fortalecer as lutas por reconhecimento e inclusão do povo negro, que construiu este país, mas que costuma ter a sua contribuição diminuída na narrativa que, comumente, tem-se da construção do Estado-Nação brasileiro. Veja-se o seguinte trecho do romance, com a fala de Damião, homem negro e principal personagem, em momento já alforriado, em sua tomada de consciência existencial e racial:

Como aceitar que no Brasil ainda subsistisse a propriedade do homem sobre o homem, através do cativeiro? E como admitir que, numa terra onde a maioria da população era constituída de negros, ou destes descendia a minoria branca que se mantinha quase sempre ociosa, continuasse a explorar a maioria cativa no regime do trabalho forçado [...]

Agora, pergunto a vocês: quando acabará em nossa pátria o crime contra a raça negra? Todos os dias, nas cidades e nas fazendas, há negros morrendo no cativeiro! Isso não pode continuar! Os negros ajudaram a construir esta nação. A Independência foi também conquistada pelos homens de cor! Eles deram seu suor e seu sangue para que o Brasil prosperasse e se emancipasse. E esses negros continuam no relho. E esses negros são escravos! (MONTELLO, 2005, p. 371373).

Para existir e resistir, os mocambos e quilombos necessitavam se ocultar, escolhendo territorialidades que não estavam ao alcance do controle social e jurídico do regime escravocrata. Nesse sentido, o romancista escreve:

$\mathrm{O}$ rio largo, enxameado de piranhas, ficava a quatro dias de viagem pelos meandros da floresta. Para alcançar a vila mais próxima, era preciso passar para 
a outra margem, remando contra a correnteza, e andar outros quatro dias, sempre dentro da mata, por um caminho que só os negros conheciam.

Julião tinha sido o primeiro a chegar ali, já fazia alguns anos. Viera da Fazenda Bela Vista, trazendo consigo a mulher e os dois filhos, uma menina e um menino, ambos ainda crianças, suportando uma caminhada tão penosa, sempre com a impressão de estar sendo seguido, que levara quase um mês para chegar àquela abertura da mata, à beira de um pequeno lago (MONTELLO, 2005, p. 21).

Os escravizados fugiam da opressão dos "senhores", buscando no quilombo uma territorialidade de liberdade e interação com outros sujeitos resistentes. Ao fazer a introdução da obra de Frantz Fanon, Lewis Gordon (2008) lembra que a liberdade requer um mundo de "outros", indagando, todavia, o que costuma acontecer quando "os outros" não nos oferecem reconhecimento; um dos desafios instigantes de Frantz Fanon para o mundo moderno parece residir nesse ponto, eis que, na maioria das discussões sobre racismo e colonialismo, há uma crítica da alteridade, da possibilidade de tornar-se o "outro".

Frantz Fanon, entretanto, argumenta que o racismo força um grupo de pessoas a sair da relação dialética entre o "eu" e o "outro", uma relação que é a base da vida ética; a consequência disso é que quase tudo é permitido contra tais pessoas (escravizadas), e, como a violenta história do racismo e da escravidão revela, tal licença é frequentemente aceita com um zelo sádico; dessa forma, a luta contra o racismo antinegro não seria, portanto, contra ser o "outro", mas seria uma luta para entrar na dialética do "eu" e do “outro" (GORDON, 2008).

Os quilombolas fugiam para as zonas, territorialidades não dominadas, nas quais pudessem ser reconhecidos como sujeitos, ainda que fosse apenas o reconhecimento entre "os seus", os "iguais", em razão de as suas subjetividades terem sido renegadas pelo sistema escravocrata que os tratava não apenas com desprezo, mas com sadismo. A única esperança era fugir e se unir aos iguais, aos semelhantes, já que o colonialismo havia criado um critério, alicerçado juridicamente, de desigualdade, baseado na cor da pele. Entre os castigos, as humilhações, o sadismo e a morte, a fuga representava uma esperança de concretização ao direito à liberdade e à própria igualdade: neste caso, entre os próprios sujeitos resistentes. O diálogo entre Prudêncio e Balbino, personagens negros, que haviam fugido recentemente para o quilombo, evidencia isso:

No fim do outro inverno, o Prudêncio e o Balbino ali chegaram de surpresa, trazendo no corpo as marcas das últimas chicotadas que o próprio dr. Lustosa fazia questão de dar, com a força e a ira de seu único braço: 
- Tem sordado do governo te procurando - preveniu o Prudêncio, que falava depressa e cantando. Nós apanhou como bicho, e não disse onde tu tava. Até nos jorná de São Luís se falou que tu fugiu, depois de tocar fogo na casa de teu sinhô. E o Balbino completou:

- Quando nos sortaram, nós fugiu. Quirino jurou que foge. Também o Bastião e o Nonato. Não se aguenta mais o home. Todo dia tem gente no tronco prele surrar. A véia Coió, coitada, morreu apanhando. E era o doutô que tava com o chicote. $[\ldots]$

Egressos de outras fazendas longínquas, novos negros ali chegaram, e não tardou que, uma noite, à hora em que descem os voduns nos terreiros sagrados, ressoasse um tambor, abafado pela floresta circundante. Também apareceu uma cabaça. E ainda um ogã (MONTELLO, 2005, p. 22-23).

A parte final da passagem acima é interessante porque demonstra o quanto os quilombos e mocambos eram territorialidades de liberdade e re(e)xistência. Ali, o exercício dos cultos ancestrais não sofria a vigilância implacável: deuses, orixás e voduns poderiam interagir com seus elos na terra, através das possessões. Para Frantz Fanon (1968), aliás, as sessões de possessão e despossessão que se organizavam, tais como o vampirismo, possessão pelo djim, pelos zumbis, por Legba, o ilustre Deus do Vodu, tidas como pulverizações da personalidade, desdobramentos e dissoluções, teriam exercido uma função econômica primordial na estabilidade do mundo colonizado, pois na ida, os homens e as mulheres estavam impacientes, indóceis, irritados, enquanto, já na volta, estariam tomados pela calma, que retornava à aldeia, cheios de paz e imobilidade.

Apesar de haver o propósito deliberado de ocultamento das territorialidades quilombolas, a fim de sua proteção, estas, mais do que se pensa, interagiam com os antagonistas, "o mundo civilizado", o "outro" opressor, que vivia à custa da escravização. Isso é evidenciado quando o escritor faz a descrição de Samuel, personagem negro, que substituiria Apolinário, personagem, também, negro, nas tarefas de troca:

Daí ter sido escolhido para substituir o Apolinário (que ultimamente dera para beber) na missão de ir a um dos povoados mais próximos, de mês em mês, para trocar o milho, o feijão e as frutas do quilombo, pelas coisas que ali faltavam como o sal, o fósforo, as velas de estearina, os côvados de pano e a munição das espingardas (MONTELLO, 2005, p. 30).

À medida que cresciam, os quilombos iam aperfeiçoando o seu sistema de produção, em regime eminentemente comunitário e solidário, inclusive oportunizando às crianças, por exemplo, que vivenciassem a sua infância, já que estas saiam do papel de mão-de-obra em potencial e explorada já nos primeiros passos, a qual não poderia ter desperdiçada sua energia infantil. Sobre isso, veja-se a descrição do escritor: 
Por esse tempo, já o quilombo tinha a casa de farinha, a engenhoca, o seu pequeno cemitério. Desde cedo, ouvia-se ranger a bolandeira. Pouco antes, ainda com as derradeiras sombras da madrugada, uma sineta batia. E o vento, ao ramalhar as árvores da mata, fazia também gemer as folhas dos roçados, que iam entrando pela selva. As galinhas, os patos e os marrecos misturavam-se aos porcos e aos negrinhos que corriam entre os casebres, e eram muitas as cabras, de úberes apojados, que davam o leite que ali se tomava (MONTELLO, 2005, p. 31).

Evidentemente, essas territorialidades comunitárias, espécies de paraísos nos infernos coloniais, não estavam imunes aos ataques. As suas re(e)xistências só eram toleradas enquanto não pudessem ser combatidas. Na primeira oportunidade, seriam expurgadas e dizimadas. Assim, os quilombos estavam sempre em completo alerta, a fim de formar a sua resistência aos repentinos e traiçoeiros ataques. A seguinte descrição do escritor confirma tal raciocínio:

De vez em quando, por uma notícia vinda de longe, ou pela susta precipitada de um dos vigias, corria no quilombo um alvoroço de guerra. Nessas ocasiões, o Julião à entrada de um casebre, ajudado pelo filho, distribuía as armas aos companheiros, e cada negro se precipitava para o seu posto, com uma espingarda, uma lança, um chuço tosco, ou apenas um arco e algumas flechas enquanto as mulheres recolhiam os filhos para dentro das palhoças e ali se escondiam com eles (MONTELLO, 2005, p. 31).

A permanência no quilombo potencializava a tomada de consciência da diáspora. Por quais razões estavam ali, separados por um imenso oceano de suas terras e de seus povos? O que justificava a escravidão? Após sobreviver à miséria da travessia, as humilhações dos senhores de escravos, o que lhes restava? O que reservava a futura Nação dos tristes trópicos para os seus descendentes? Como reexistir a tudo isso e entender essa lógica existencial? O escritor tenta responder a isso ao fazer a descrição de Julião, personagem negro, fundador do quilombo e pai de Damião, este último protagonista do romance:

Calado de natureza, Julião parecia fechar-se mais em si mesmo, nos longos silêncios que frequentemente se concentrava. Ele sabia que vinha de estirpe ilustre, quase toda dizimada na longa viagem do lerdo navio negreiro que o trouxera da África para o Maranhão, e guardava, nítidas, as imagens de sua terra e de seu povo, do outro lado das águas imensas. Se não se atirara ao mar, durante a vagarosa travessia, como muitos dos companheiros de viagem, foi porque a si próprio atribuíra o comando de outros negros, assim que se lhe ensejasse ocasião propícia para vingar-se do imerecido cativeiro (MONTELLO, 2005, p. 31). 
Como já se mencionou, os quilombos não estavam totalmente isolados, pois, apesar de proibidos, mantinham relações comerciais com fazendeiros, comerciantes, pretos forros e outros segmentos da sociedade interiorana, tanto que muitos escravizados saiam dos quilombos para comprar e pegar em armas, a fim de manter a integridade da comunidade (ARAÚJO, 2014), como forma de fugir ao inferno fanoniano (FANON, 2008). Sobre essas relações com a sociedade envolvente, perceba-se a fala de Julião, já descrito anteriormente:

- Óia, Damião: home nenhum tem direito de fazer outro home seu escravo, só porque nasceu branco e o outro preto. Quarquer um nasce e morre do mesmo jeito. A doença que dá em preto, dá no branco. A vida é iguar para todo mundo. Ninguém quer ser escravo, tudo quer ser livre. Cativeiro de negro tem de acabar. Para acabar só tem um jeito: é os preto se juntar. No Brasil tem muito preto, mas tudo espaiado, uns aqui, outros ali. Não há lugar sem quilombo. E tudo no mato escondido, como nós. Tu te lembra: quando nós chegou não tinha ninguém. Hoje tem gente muita. Mas se véve assustado. Tudo com medo de vortar pro cativeiro. De noite eu sonho que os branco tão chegando e pulo da rede, cum a mão na espingarda. Não se tem sossego. O nego Cosme, que tinha mais gente que nós, não aguentou a guerra dos branco. O Balaio também acabou se entregando. Tou vendo a hora dos branco chegar aqui pra dar cabo da gente. Eu podia garrar tu, mais tua mãe e tua irmã, e ir embora. Só se eu não me chamasse Julião. Mas me chamo. Foi eu que fez o quilombo, tudo aqui tá dentro do meu corpo. Cheguei agora num ponto que não posso parar nem vortar: tenho que ir para frente. A arma que nós tem aqui é pouca. E a munição não dá para nada. Perto de nós não tem onde comprar. Também não tem de quem tumar. Tou pensando mandar o Samué a São Luís. Ele é arteiro, assunta tudo, vê as casas que vende arma, óia se nós pode comprar. Cum arma na mão, a gente também morre, mas morre pelejando, morre cumo home. Ou antão sai vivo, e junta mais preto, inté acabar cum cativeiro. Se eu cair, tu fica no meu lugar. A gente não pode é fraquejar. Quem fraqueja, Deus não ajuda. Vai pro inferno aqui mesmo (MONTELLO, 2005, p. 32, grifo nosso).

Como territorialidades afastadas do alcance de controle social e jurídico, os quilombos podiam permitir que seus sujeitos vivenciassem experiências que, até hoje, no Brasil, o Estado e os grupos conservadores tendem a reprimir, como o uso da maconha, também conhecida no Maranhão, como "diamba" (djamba). A respeito disso, o escritor descreve os pretos velhos "diambeiros" do quilombo:

Os velhos fumadores de diamba, que sempre formavam um grupo à parte, isolados dos companheiros, passavam uns aos outros, nas noites claras, o cigarrinho mal enrolado, até que tudo ao redor se distanciava, só ficando um mundo vago, violáceo, já silenciado o tambor do terreiro, fechado os casebres, todo o quilombo adormecido, com um ou outro cão espantadiço a latir à toa, e o vento a soprar o seu sussurro de rio invisível (MONTELLO, 2005, p. 36). 
É nesse momento de relaxamento, contemplação e simbiose dos sujeitos entre si, com a natureza e com o transcendental, que o romancista inicia a narrativa de ataque ao quilombo, como se a "lombra" tivesse transcendido para a paranoia. A imagem é bastante representativa: no ápice da liberdade do ser, momento no qual os sujeitos estão livres e desfrutando de sua liberdade máxima, o projeto moderno dá as caras, ou melhor, apresenta as suas armas, promovendo o ataque ao quilombo e transformando a viagem psicodélica em espécie de paranoia. O projeto colonial não tolera quaisquer liberdades que não tenham passado por um processo de negociação e espoliação. E, no caso dos escravizados, estes não eram considerados sujeitos, não havendo espaço ou subjetividade que permitisse falar sobre negociação com sujeitos que estavam fora da zona do ser, zona dominada pela "brancura" 3 . Nesse sentido, o escritor descreve o ataque ao quilombo:

Foram ele que viram, na vaguidade onírica que os envolvia, uns homens armados que confluíam para o quilombo aos dois, aos três, cercando, invadindo a palhoça onde se guardavam as armas calando os cães a golpes de lanças. Um dos fumadores quis levantar-se e gritar, não sabendo distinguir o sonho e a realidade, e caiu para trás, golpeado em pleno peito, ao mesmo tempo que outros homens iam chegando, também armados, e começaram por tirar de sua palhoça o Julião, já de mãos amarradas para trás, e mais o filho, tonteado por uma coronhada na cabeça.

Todo o quilombo veio para fora os filhos pequenos agarrados à saia das mães. Por toda a parte, gritos e choros, sem que os negros pudessem disparar um só tiro. Muitos deles jaziam mortos, dentro de suas palhoças, ou em frente às portas, atravessados pelo pontaço das lanças. Os cães latiam, no atropelo da confusão (MONTELLO, 2005, p. 36-37).

Dizimados ou tornadas invisíveis, as histórias das resistências quilombolas serão varridas da narrativa da construção do Estado-Nação, pois tal mito não permitiria que sujeitos “incivilizados", em estágio de "pré-civilização" tivessem capacidade intelectual, cognitiva, de entender os "novéis" valores de "liberdade, igualdade e fraternidade", de pronúncia tão suave (liberté, egalité et fraternité) na boca das elites colonizadas: tais valores eram frutos do desenvolvimento da razão "iluminista", gestado pela intelectualidade europeia, frutos dos "méritos" da branquitude.

\footnotetext{
${ }^{3}$ A terminologia "brancura" é emprestada de Alberto Guerreiro Ramos (1995), que a preferia no lugar de "branquidade", "branquitude", esta última terminologia mais usual nos estudos sobre relações raciais. Sobre o pensamento e obra de Guerreiro Ramos, $c f$. AZEVÊDD, Ariston. A sociologia antropocêntrica de Alberto Guerreiro Ramos. Tese (Doutorado em Sociologia Política), UFSC, 2006, 355 f; CRUZ, Leonardo Borges da. A formação discursiva pós-colonial em Alberto Guerreiro Ramos. Revista da ABPN: Associação Brasileiras de Pesquisadores Negros, v. 10, n. 25, mar./jun, p. 141-164, 2018.
} 
Portanto, não era possível que sujeitos "boçais" pudessem alcançá-los por si mesmos, pois a incultura dos negros, proclamada pelo colonialismo, devia logicamente levar a uma exaltação dos fenômenos culturais não mais nacionais, mas continentais e singularmente racializados (FANON, 1968). Assim, no máximo, os subalternizados poderiam desfrutar os valores liberais recentes, desde que eles fossem inicialmente racionalizados e gestados pela benevolência eurocêntrica em seu favor.

Tipicamente, o Iluminismo europeu é considerado o principal e, às vezes, o único período histórico relevante para o entendimento do ideal de civilização ocidental moderna. É por isso que a análise do colonialismo moderno tende a focar nos impérios e nas formações dos estados-nações dos séculos XVIII e XIX, que desempenharam importante papel neste processo, nomeadamente, Inglaterra e França (MALDONADO-TORRES, 2019, p. 30).

Em vez disso, a narrativa dirá que a luta pela abolição foi predominantemente um projeto liberal, da intelectualidade urbana, letrada e branca, fruto do iluminismo e gestado na própria Europa, não se permitindo dizer que os quilombos representaram fissuras que levaram ou que pelo menos tenham contribuído para a insustentabilidade do regime escravocrata.

O discurso liberal dos abolicionistas não aceitava as lutas dos escravizados como fato político, mas, de fato, como simples manifestação de homens que "mantidos até hoje ao nível de animais", jamais poderiam participar do processo de mudança social no qual eram os principais interessados (MOURA, 1981).

É que essa "rebeldia negra" antecede em muito o movimento abolicionista. Enquanto a primeira desde o século XVII já se consubstanciava em um fato histórico tão relevante como a República de Palmares, o movimento abolicionista somente se manifestará, organizada e politicamente, quando o sistema escravista entra em sua crise irrecuperável do final do século XIX. É exatamente a este movimento tardio que se deseja dar o mérito da Abolição. Ao contrário. Se méritos devem ser computados deverão ser creditados à rebeldia negra. Se houve limitações imperdoáveis elas devem ser computadas aos tímidos abolicionistas que a concluíram.

Os abolicionistas, com a exceções que veremos depois, se desejavam o fim da escravidão lenta, de um lado, temiam, de outro, aquela "vingança bárbara e selvagem" a que Nabuco se refere cautelosamente. No entanto, conforme já vimos, os quilombos nunca foram grupos fechados e já na República dos Palmares e no quilombo de Ambrósio, como em tantos outros, elementos de outras etnias, marginalizados pelo sistema escravista, se refugiavam naqueles espaços para participarem da vida comunitária que encontravam no quilombo (MOURA, 1981, p. 81-82). 
Ocorre que essa rebeldia precisava ser expurgada das narrativas, aliando-se a isso um processo de inferiorização/subalternização dos negros. Assim, o mundo colonial é um mundo maniqueísta, pois não basta ao colono limitar fisicamente, com o auxílio de sua polícia e de sua militarização, o espaço do colonizado; como que para ilustrar o caráter totalitário da exploração colonial, o colono faz o colonizado uma espécie de quintessência do mal (FANON, 1968) e não reconhece qualquer subjetividade. No romance, isso pode ser confirmado através das falas contrapostas do "alferes louro", personagem branco, e de Julião, homem preto, fundador do quilombo, os quais apresentam suas visões sobre a escravidão, após o escritor descrever a investida cruel contra a comunidade quilombola:

Com a pistola na não, o alferes louro, de passo pesado, que comandava a tropa, ia avisando:

- Lugar de escravo é na senzala, debaixo das vistas de seu senhor. Todos vocês vão voltar para os seus donos. Ou então morrem aqui mesmo, que eu tenho ordem de matar.

Julião se viu perto do filho:

- Nós foi traído - conseguiu dizer-lhe.

A cada momento estrondavam os tiros, uns aqui, outros adiante, outros mais dentro da mata, e de repente um rolo de fumaça subiu, ganhou altura, e logo as labaredas lamberam a palha de um dos casebres, no começo do fogaréu imenso que irrompeu de vários pontos ameaçando estender-se para a mata circundante. Uma a uma, as palhoças iam ardendo, e só se viam mulheres correndo para a borda do lago, seguidas atropeladamente pelos filhos e os cães, enquanto os homens retraíam, de olhos crescidos e mãos atadas, vendo avançar o clarão vermelho que engolfava todo o quilombo (MONTELLO, 2005, p. 38).

O mundo colonial, portanto, é compartimentado, maniqueísta, mundo seguro de si, que esmaga com suas pedras os lombos esfolados pelo chicote, onde são encurralados os oprimidos, que devem permanecer no "seu lugar", não podendo ultrapassar os limites (FANON, 1968). Sobre isso, veja-se o escritor descrevendo a destruição do quilombo, através do olhar de Damião, herói negro do romance:

Damião guardaria por toda a vida a imagem desse novo dia clareando o quilombo desfeito. Só então reparou que muitos negros choravam. Vários deles, exaustos, estavam sentados, a olhar os seus bens perdidos, com a consciência da volta ao cativeiro. Seu pai permanecia de pé, o semblante contraído, calado. Ensaiara falar-lhe, e ele não respondera, petrificado no seu silêncio, as sobrancelhas travadas (MONTELLO, 2005, p. 39).

Nesse contexto, Frantz Fanon (2008) escreveu que, em uma visão eurocêntrica, o negro tem uma função: representar os sentimentos inferiores, as más tendências, o lado obscuro da alma; no inconsciente coletivo do homo occidentalis, o preto, a cor negra, 
simboliza o mal, o pecado, a miséria, a morte, a guerra, a fome e tal imagem pode ser representada pela cor negra das aves de rapina. É diante desse dilema, com a subjugação do quilombo, retratado no romance, que o colonialismo se consolidará, marcando a vida urbana pelo racismo.

\section{O COLONIALISMO QUE SE CONSOLIDA: A VIDA URBANA E OS DILEMAS}

\section{DO RACISMO}

Neste ponto, será discutido o papel do negro em uma sociedade racializada, que não permitiu a ascensão das pessoas negras ou, quando as aceitou, tolerou-as, desde que não apresentassem contraposição ao projeto hegemônico inaugurado pelo colonialismo.

Abdias do Nascimento (1980, p. 81) diz que o Brasil não experimentou uma luta de independência, pois o 07 de setembro foi resultado da pura manipulação de superestrutura, entre aristocratas rurais, políticos e cortesãos, todos brancos; enquanto as massas do povo brasileiro - especialmente as massas afro-brasileiras - não participaram na definição e na decisão independentista, assim como não obtiveram nenhum fruto ou benefício desse evento; foram simples joguetes nas mãos das classes dirigentes, constituídas de portugueses e brasileiros; objeto ou telão de fundo, as massas negras não tiveram a oportunidade de influir e atuar no desenrolar daquele episódio histórico no sentido de infundir-lhe uma significação profunda de mudança nas estruturas de dominação e opressão vigentes; formalmente independente, o Brasil continuou seguindo orgulhosamente o conservador modelo português, tendo sido um dos primeiros a escravizar os africanos no Novo Mundo e sendo o último a 'libertá-los' do cativeiro.

Nessa busca por reconhecimento, primeiro, o negro deve ter consciência de si: reconhecer-se como um sujeito diaspórico. De onde veio? Por que está aqui? Não sendo possível retornar, qual o seu projeto nestas territorialidades? No romance, o escritor descreve a tomada de consciência de Damião, nosso herói negro e protagonista da história:

E de repente numa reação impulsiva de seu brio, Damião voltou a fixar o pensamento na miséria de sua condição. Por que era escravo? E por que também eram escravos os negros que enchiam a capela? Agora, ali estava o bispo, como emissário de Deus. Deus estaria de acordo com aquela distinção? Uns livres, outros escravos? Uns sentados, outros de pé? No entanto, ali na fazenda, os brancos constituíam a minoria privilegiada, que oprimia a multidão de negros, 
sem lhes dar direito a nada, nem mesmo ao banco vazio da capela. E os negros eram a maioria e a força, o vigor e o trabalho. Não seria o caso de perguntar ao bispo o que fazia Deus que não tirava os pretos do cativeiro? Ou o Deus era dos brancos e não dos negros? (MONTELLO, 2005, p. 97).

Frantz Fanon (2008) dirá que, mais diretamente, todo indivíduo deve rejeitar suas instâncias inferiores, suas pulsões, jogando-as nas costas de um gênio mau que será aquele da cultura à qual pertence (isto é, o negro); essa culpa coletiva é carregada por aquele que se convencionou chamar de bode expiatório, que para a sociedade branca baseada em mitos de progresso, civilização, liberalismo, educação, luz, refinamento será precisamente a força que se opõe à expansão, à vitória desses mitos: essa força brutal, opositora, é o negro que a fornece.

A civilização branca, isto é, a cultura europeia, impôs ao negro um desvio existencial, demonstrando Frantz Fanon (2008) que aquilo que se chama de alma negra é frequentemente uma construção do branco. No romance, esse questionamento é revelado, quando o escritor, ao descrever o pensamento de Damião, protagonista negro, informa que os negros só se sentiam livres na Casa-Grande das Minas, local de culto africano, em São Luís, atualmente, tombada pelo IPHAN:

Muitos deles, ou quase todos, só teriam a contar, como lembranças da vida, uma crônica de sucessivas humilhações e amargura. Mas ali se transfiguravam, repostos na sua aldeia africana.

Já fazia mais de três séculos que os primeiros negros tinham chegado ao Maranhão, ainda com a cidade circunscrita ao seu forte, a algumas ruas tortas, ao casario de palha, a uns poucos sobradinhos de pedra. Ano após ano, vieram vindo outras levas de escravos, embarcados em Angola, na Guiné, em Moçambique, no Congo e na Costa da Mina, e muitos ficaram pelo caminho, jogados ao mar, pois não tinham conta os que morriam no porão dos tumbeiros, esmagados por outros negros, que ansiavam respirar o ar das escotilhas. E eram também sem conta os que se deixavam morrer, com o sentimento de sua revolta e de seu infortúnio. Para obrigá-los a viver, um chicote estalava, e eles dançavam com o navio, que parecia cambalear nas ondas de mar alto, rijamente fustigado pelo sopro das rajadas. Só uns tantos chegavam ao fim da viagem. E tinham sido eles, os pobres pretos esqueléticos, de grandes olhos febris, as pernas bambas e chagadas, que em verdade ergueram a cidade, com seus palácios, seus sobradões de pedra e cal, suas igrejas, e sua muralha junto ao mar, sem que nem por isso lhes fosse restituída a liberdade. Em verdade, só eram livres ali, na Casa-Grande das Minas, e enquanto ressoavam os tambores (MONTELLO, 2005, p. 279-280).

Dessa maneira, os negros serão comparação, ou seja, estarão sempre se preocupando constantemente com a autovalorização e como ideal do ego, pois a cada vez que entram em contato com um outro (o branco), costumam advir questões de valor, de 
mérito (FANON, 2008), questionando-se a sua condição; já o contrário não é verdadeiro, pois o branco, diante dos privilégios da brancura/branquitude, no máximo, pensará que tais privilégios advém de seus méritos, de uma ética que contempla os frutos do trabalho ou da exploração de outros sujeitos. O romance, nesse contexto, mais uma vez evidencia essa questão, quando o escritor, a partir do pensamento de Damião, descreve o questionamento dos negros, em seu cativeiro, nos raros momentos de exercício livre de suas manifestações da zona do ser:

Agora, olhando os negros dançando em volta do boi, alguns já velhos, de carapinha pintando sob o luar, lembrava os horrores que ouvira de outros negros, inclusive de seu pai, sobre a longa viagem da África para São Luís, meses a fio, no mesmo espaço do porão imundo. Eram trezentos pretos, às vezes mais, no mesmo vão exíguo: frequentemente apertados contra os outros, na atmosfera sufocante, lutando para alcançar os respiradouros, ou abrindo a boca rachada e impaciente, na ânsia de beber um pouco de água. Não raro, lá fora, chovia copiosamente, e eles ali, sedentos, ouvindo a água do temporal bater nas velas e escorrer no convés. Cerca de um terço dos que tinham embarcado não chegava sequer ao meio da travessia; muitos deles, desesperados, conseguiam desprenderse das correntes que os manietavam, e atiravam-se ao mar; outros morriam, sufocando-se com a própria língua. Os que chegavam ao termo da viagem mal tinham forças para caminhar; e não eram poucos os que, andando tropegamente pela orla das praias, a caminho das cafuas de escravos, tombavam na areia molhada, e ali mesmo eram enterrados. Como se esses tormentos não bastassem, restava aos sobreviventes a provação do cativeiro. Depois de tudo isso, como os negros ainda podiam dançar, ao som dos tambores, no terreiro das fazendas? $\mathrm{Ou}$ ali na praça, ao som das zabumbas e das matracas de pau? Aquele negro alto, de máscara no rosto, a tocar a sua zabumba, era o que mais impressionava Damião: embora imóvel, não perdia o compasso, na movimentação das mãos ritmadas, que acompanhavam o bater das matracas (MONTELLO, 2005, p. 367).

Na sua imediaticidade, a consciência de si é simples ser para si; para obter a certeza de si mesmo, é preciso a integração do conceito de reconhecimento; “o outro", igualmente, espera nosso reconhecimento, a fim de se expandir na consciência de um si universal; cada consciência de si procura o absoluto, que quer ser reconhecida enquanto valor primordial, desvinculado da vida, como transformação da certeza subjetiva em verdade objetiva; ao reencontrar a oposição do "outro", a consciência de si tem a experiência do desejo; primeira etapa do caminho que conduz à dignidade do espírito (FANON, 2008). Leia-se o seguinte discurso de Damião falando aos seus alunos, fala que lhe rendeu o ostracismo social e a perda do emprego como professor ${ }^{4}$ :

\footnotetext{
${ }^{4} \mathrm{O}$ episódio faz lembrar a história de Hemetério José dos Santos, homem negro retinto, nascido em Codó/MA, por volta de 1858, que, com sua erudição, conseguiu ser professor no Colégio Pedro II e Colégio Militar. Entretanto, em virtude de seu ativismo contra a escravidão e sua cor, foi vítima de muito racismo.
} 
- A escravidão é um abuso: o homem não pode explorar o homem, mantendo outros homens cativos, só porque estes têm a pele negra. A maldição da cor é uma falsidade e uma estupidez. A circunstância de ter nascido com esta pele não exclui a minha condição de homem: sou um ser humano, como vocês; tenho uma alma, tenho a consciência de meus direitos e deveres, e também o sentimento de minha dignidade e de minha honra. O cativeiro é um crime, e crime que se pratica para outros homens. Não há nada que justifique a escravidão (MONTELLO, 2005, p. 372).

Nesse contexto, a memória da escravidão, ativamente preservada como recurso intelectual vivo em sua cultura política expressiva, pode ajudar a gerar um novo conjunto de respostas; os escravizados tiveram de lutar - muitas vezes por meio de sua espiritualidade - para manterem a unidade entre a ética e a política, dicotomizadas pela insistência do colonialismo em afirmar que o verdadeiro, o bom e o belo possuíam origens distintas e pertenciam a domínios diferentes do conhecimento (RODNEY, 1975). Essa luta é evidenciada quando Damião fala mais para seus alunos, antes de perder o emprego no colégio:

É branco, pode matar um negro; não será julgado, não irá para a cadeia. Todos os dias, nos jornais de São Luís, vocês podem ler anúncios de negros fugidos. Não é um, não são dois - são muitos. Se os negros fogem da casa de seus senhores, é porque estão cansados da chibata e do tronco. Querem ser livres, como vocês, como eu. Nesta guerra com o Paraguai, mitos negros estão nas frentes de batalha (MONTELLO, 2005, p. 373).

Fato bastante ignorado e que passa despercebido ou com discussão acessória é a importância do desenvolvimento das armas de fogo no processo de dominação e escravidão colonial. A colonização e o domínio do mundo inteiro pelos brancos apenas se tornou possível quando as armas de fogo europeias alcançaram certo grau de eficácia no século XIX; similarmente, a invenção de um manancial de novos instrumentos de destruição produziu um certo desencorajamento psicológico, que se refletiu na atividade prática, na luta pela independência dos povos colonizados (RODNEY, 1975).

Além disso, a escravidão racial foi parte integrante da civilização ocidental e se considera em detalhe a relação senhor/escravo, que funda tanto as críticas como as afirmações da modernidade desenvolvidas por intelectuais negros (GILROY, 2001). Nesse ponto, Damião faz contundentes questionamentos a respeito dos privilégios da branquitude, na sua famosa aula aos alunos da elite maranhense: 
- A liberdade não pode ser um privilégio da raça branca, porque é uma aspiração natural da condição humana. Toda restrição à liberdade constitui uma violência contra essa aspiração. Ninguém tem o direito de sequestrar um ser humano, privando-o da dignidade essencial da sua liberdade. E é isso que se vem fazendo aqui, com os negros e os seus descendentes. Vocês são livres e são moços: não permitam que haja escravos no Brasil. $\mathrm{O}$ cativeiro é um crime, e um crime coletivo, de que toda a Nação é responsável! Crime da Nação contra si mesma! Crimes do homem contra a humanidade! (MONTELLO, 2005, p. 374).

E essa humanidade deve incluir também os negros. É nesse panorama que se fala da ideia de um Atlântico Negro, sugerindo-se que se deve reconsiderar as possibilidades de se escrever relatos não centrados na Europa, isto é, relatos sobre como as culturas dissidentes da modernidade têm desenvolvido e modificado este mundo fragmentado, contribuindo-se amplamente para a saúde do planeta e suas aspirações democráticas (GILROY, 2001).

Portanto, o Atlântico Negro, dentre outras coisas, possui uma disposição geralmente favorável diante de movimentos sociais que desafiem o sistema numa insurgência revolucionária que complemente, amplie e repudie um iluminismo europeu incompleto e codificado racialmente (GILROY, 2001). No romance, Damião tem uma história ancestral, ou seja, tem um relato não centrado na ascendência europeia. A personagem velha Santinha, negra e costureira, relembra essa ancestralidade ao tentar tirar Damião de seu estado depressivo após este perder o trabalho como professor:

Mãe Maria Quirina me contou que o pai de você, na África, era gente de peso e mando. Preto de vergonha, com muita coragem. Genoveva Pia também me falou dele com os olhos cheios de água. Um preto valente e que sabia mandar. Não conheceu nenhum como ele. A esperança dela era você. Que ia ser grande também. Para ensinar os brancos a respeitarem os pretos. De repente o Damião mudou. Até parece que lhe fizeram feitiço. Mandinga braba, Damião. Olho grande. Inveja de branco. Você não é um preto como os outros. Se convença disso. Conheça o seu lugar. Você tem a quem sair, não pode botar fora o sangue que tem no corpo. Não, não pode. Quando você chega na casa das Minas, Mãe Maria Quirina vem buscar você no corredor, e o tambor vira, com o vodum baixando, quando você entra no terreiro. Sabe por quê? Porque você é grande, Damião. Gente de cima. De muito alto (MONTELLO, 2005, p. 480, grifo nosso).

Encerrado o fenômeno social e jurídico da escravidão, pretende-se discutir como as pessoas negras ficaram renegadas ao acesso às políticas públicas, não havendo qualquer preocupação estatal ou das elites em incluí-las no que se denominou de um projeto de Estado-Nação. 
Deixados sem quaisquer perspectivas de inclusão, antes e após a abolição, restou à população negra apenas o respeito aos deveres, os quais incluíam a proibição de realização de suas manifestações culturais e religiosas. Registre-se a fala de Barão, personagem negro, a respeito do processo de criminalização das culturas e religiosidades negras:

- Não viste, no País de hoje, ou de ontem (já não me lembro bem), que o chefe de polícia proibiu os fandangos, os torés, as cheganças e os congos? Considero isso mais grave que o crime de dona Ana Rosa Ribeiro. Acabar com os folguedos dos negros? Em que terra estamos, seu Damião? Amanhã, com o mesmo capricho estúpido, vão querer acabar com o tambor das crioulas e das negras-minas. Nesse dia, eu vou aparecer no largo do Carmo tocando tambor. E debaixo do Pelourinho, para chamar mais a atenção (MONTELLO, 2005, p. 504-505).

Nessa perspectiva, o mundo colonizado seria um mundo cindido em dois, com uma linha divisória, cuja fronteira é indicada pela repressão garantida pelos quartéis e delegacias de polícias; nas colônias, o interlocutor legal e institucional do colonizado, o porta voz do colono e do regime de opressão geralmente é o militar, o soldado (FANON, 1968). É essa polícia que será o braço armado para a repressão não só dos quilombos, mas que se manterá mais presente, como instrumento de controle físico e psicológico, nas zonas urbanas, a fim de dar à necessária segurança que a branquitude tanto idealiza para si à custa do povo negro: a violência e o terror são personificados na escuridão, no pânico noturno, na cor preta, na população negra.

Ocorre que essa personificação do mal em cima dessa população, como a criação de estereótipos raciais, trata-se de um álibi para não discutir as razões verdadeiras do processo de exclusão das mesmas das políticas públicas, que se fizeram ausentes desde a celebração dos pactos narcísicos em torno dos privilégios que decorrem da "não discussão" dos efeitos da escravidão brasileira após a tríade temporal jurídico-racial: 1888, abolição,1889, proclamação da República, e 1891, primeira constituição da republicana. Em torno desses questionamentos, o Presidente da Província do Maranhão, o personagem Moreira Alves, homem branco, diz para Damião, após recebê-lo no Palácio do Governo: 
- O senhor pôs o dedo na ferida, Professor. O problema não é político - é social. É essa também a minha opinião. Também penso como o senhor quanto à abolição. Já se pode sentir, nestes poucos meses transcorridos depois do 13 de maio, que ela foi um movimento passional, tanto de um lado quanto do outro. Desde 1871, com a Lei do Ventre Livre, devíamos ter adotado algumas providências fundamentais, que permitissem a transformação do trabalho escravo em trabalho livre, sem prejuízo para a economia do país. E isso não foi feito. De repente o problema nos entrou pela porta da rua e nos encontrou despreparados para resolvê-lo (MONTELLO, 2005, p. 623-624).

Após a abolição, a ausência de políticas públicas reafirmou a invisibilidade dos quilombos e da população negra, de maneira geral, que, além de silenciados, passaram a ser estigmatizadas como obstáculos aos processos de "desenvolvimento"; as populações negras rurais, isoladas pela falta de comunicação, transporte, educação, saúde e políticas públicas e outras formas de cidadania, foram estigmatizadas, a ponto de seus moradores recusarem a denominação de quilombolas ou ex-escravizados, em que pese tais comunidades nunca deixaram de existir em suas lutas seculares no mundo agrário, parte das quais para defender territórios, costumes seculares e parentesco na organização social (GOMES, 2015). Sobre esse abandono da população negra após a abolição, Damião, protagonista negro, fala ao Presidente da Província, homem branco:

- Tenho certeza, senhor presidente. Estou vendo a hora em que os negros começarão a saquear as casas, impelidos pela fome. Daqui a pouco vai começar a estação das chuvas, e quase todos eles dormem na rua, sem ter onde se abrigar. Não sei como vai ser. É preciso que sejam tomadas algumas providências rápidas, por parte do próprio Governo; mas não as que têm sido dadas até agora, com o recolhimento dos negros ao São João, à Cadeia Púbica e no Hospital do Lira. É preciso dar a esses nossos patrícios, que são tão brasileiros quanto os outros, uma ocupação qualquer. Muitos deles, passado o entusiasmo da abolição, voltaram, de cabeça baixa, à casa de seus senhores. Mas outros, tomados de brio, com a consciência de que são homens livres, não quiseram voltar. Vagam pela Praia Grande, dormindo na orla do cais ou no interior dos barcos que ali pernoitam, e vivem disputando entre si por ínfimo preço, todo e qualquer trabalho. Outros já estão juntando o lixo na rua para comer os restos ali deixados. Não há ponto da cidade em que eles não estejam, seminus, maltrapilhos, cheirando mal, de olhos encovados, e já na iminência de cometerem desatinos. Não estou a par das medidas que o governo já tomou para ampará-los. Mas tenho certeza de que Vossa Excelência, como bom presidente que tem sido, está atento ao problema, que não é policial, como muitos pensam - é social. Para a abolição do cativeiro, só se pensou na festa - não se pensou no dia seguinte (MONTELLO, 2005, p. $623)$.

Essa situação reflete a cegueira das elites nacionais, como a do Brasil, que tomaram o poder no fim do regime colonial, mas que não passaram de burguesias 
subdesenvolvidas, cujo poder foi quase nulo e sem preocupação comum com o da burguesia metropolitana a qual pretendia substituir; em seu narcisismo voluntarista, a burguesia nacional convenceu-se facilmente de que podia vantajosamente ocupar o lugar da burguesia metropolitana (FANON, 1968).

Nesse contexto, de acordo com Frantz Fanon (1968), foi uma tendência das burguesias nacionais voltarem cada vez mais às costas ao interior (o caso Brasil é rico exemplo), às realidades do país, voltando seus olhos míopes para a antiga metrópole e para os capitalistas estrangeiros que se apoderavam de seus serviços.

Nesse cenário, a implantação da república brasileira nasce totalmente alheia aos interesses da grande população de seu país, que ficou alheia ao projeto elitista o qual se implantou. Uma república nascida de um golpe militar e gestada nos gabinetes, sem a mínima transparência e diálogo, os quais se esperariam de uma república, interessada em construir um projeto de Nação que contemplasse e incluísse negros e indígenas. Para Damião, o herói negro, essa república estava fadada ao insucesso, pois era projeto de uma pequena elite atrasada. Veja-se o seu pensamento, inclusive com certo saudosismo da monarquia, após encontrar o poeta Sousândrade, entusiasta da república:

E enquanto a traquitana sabia a inclinação do calçamento, para entrar na rua dos barbeiros, Damião procurou concatenar rapidamente as palavras, para dizer ao poeta, sem feri-lo com a sua franqueza, que não concordava com a destruição da Monarquia. Reconhecia que a República era um belo sonho político; mas também sabia que a nação ainda não estava preparada para ela. Sobretudo naquela hora. Que era o Brasil, naquele momento? Um país de analfabetos, com a cultura política limitada a uma pequena elite. Desse modo, como pensar em República. Além do mais, a pregação republicana estava sendo feita a toque de caixa, sobre o ressentimento da lei que abolira o cativeiro. Para defender a princesa Isabel, ameaçada de morte pelos senhores de escravos, os ex-cativos tinham-lhe criado uma Guarda Negra (MONTELLO, 2005, p. 630-631).

Essa república, alertava Abdias do Nascimento (1980), excluiu a população indígena e negra, preferindo navegar no devaneio europeu de embranquecimento. E, enquanto os negros permaneceram na base da escada social, durante quatro séculos, os imigrantes brancos que chegaram ao país em algumas décadas, ou, por assim dizer, há alguns dias, ascenderam rapidamente a escala social e de todos os poderes, seja o econômico, o político ou o cultural.

Por outro lado, essa vertiginosa mobilidade da sociedade brasileira não tocou a pele negra da população majoritária, pois o ideal era embranquecer o país, expurgando a 
cor negra e o sangue indígena, e, além disso, o Brasil oficial dispendeu grande esforço tentando criar a ficção histórica segundo a qual o país representaria o único paraíso da harmonia racial sobre a terra, cujo modelo deveria ser imitado pelo mundo (NASCIMENTO, 1980).

Porém, no Brasil, como costumou acontecer na América Latina, pratica-se a discriminação racial de maneira mascarada, sutil, aberta ou encoberta, pois tal discriminação utiliza as diferentes tonalidades de cor epidérmica do negro como mecanismo para conseguir que o negro desapareça através da ideologia do branqueamento, como a busca do homem ideal para obter melhores condições de vida, e com este mesmo mecanismo se destrói a solidariedade política, econômica, religiosa e familiar dos grupos negros (NASCIMENTO, 1980).

Esse racismo de tipo negativo se consolidou a partir do mito da democracia racial e da ideologia da miscigenação. No romance essas discussões são expostas com argumentos que lembram bastante aquilo que Gilberto Freyre difundiu em Casa-Grande \& Senzala. Sobre o processo de miscigenação e embranquecimento, veja-se a fala de Barão e, depois, o pensamento de Damião, ambos personagens negros:

- Estou convencido de que Deus fez o homem, mas foi o diabo que lhe deu a cor. É por isso que uma cor não gosta da outra. Em nossa terra, devagar, sem pressa, a gente vai misturando todas elas. No fim, saiu um tipo novo, que não se parece com nenhum outro. [...] O branco, que é o pai, não pode deixar de ter o seu rabicho pelo filho bastardo, e vai-lhe dando a mão como pode. Daí a quantidade de mulato doutor que se vê agora a três por dois. Já a sinhá-moça, que não passou pela dorde-cotovelo da sinhá-dona, tem é xodó pelo mulato. Nossa raça, meu caro Damião, nesse ponto, é mesmo privilegiada: o cheirinho que sai do corpo da gente é que é nossa grande arma. Não há branco que resista ao bodum de uma negra. Com as brancas é a mesma coisa: o cheirinho de um preto faz muitas delas perderem a cabeça - e o resto do corpo: se assanham logo. Louvado seja Deus! E como nos apreciam! [...]

E nisto a Benigna tornou a apontar no retângulo da porta, chamando-o agora para conhecer Julião:

- É clarinho - preveniu-lhe.

E quando ele se curvou sobre o berço, muito emocionado, sentindo os olhos úmidos, ela lhe foi dizendo, enquanto erguia o candeeiro, para dar mais luz sobre a criança:

- Tem a tua cara, meu filho. Até o nariz chato é teu. Olha a testa. Também é tua. E esse beicinho espichado. Tudo teu. É mais para branco que para preto: moreninho, como um bom brasileiro.

Damião olhava embevecido aquela pequena massa humana, ainda mole, com uns fios de cabelos úmidos, os olhinhos cerrados, os bracinhos encolhidos na camisinha de linho, e não podia deixar de lembra-se do Barão, com a sua famosa teoria de que só na cama, com o rolar do tempo, se resolveria o conflito natural de brancos e negros, no Brasil. Tinha ali mais uma vez a prova, na sua própria 
família. Sua neta mais velha casara com um mulato; sua bisneta, com um branco, e ali estava seu trineto, moreninho claro, bem brasileiro. Apagarase nele, é certo, a cor negra, de que ele, seu trisavô, tanto se orgulhava. Mas também se viera diluindo, de uma geração para outra, o ressentimento do cativeiro. Daí a mais algum tempo, ninguém lembraria, com um travo de rancor, que em sua pátria, durante três séculos, tinham existido senhores e escravos, brancos e pretos (MONTELLO, 2005, p. 500, 653-654, grifo nosso).

Essa concepção acima evidencia o quanto a política de embranquecimento atingiu o Brasil. Foi essa política que levou Damião a prosseguir dentro da madrugada de São Luís, em sua caminhada em direção ao bisneto clarinho, ao som dos atabaques algum dia trazidos da África, em especial do Daomé (SANTOS, 2015), em descrição literária que parece narrar uma caminhada de abandono das raízes africanas e sua negritude até chegar a um ideal de embranquecimento.

Aliás, nada mais representativo do que o quadro A Redenção de $\mathrm{Cam}^{5}$, de Modesto Brocos, 1895, no qual a avó negra contempla a filha, de pele mais clara, cuidar de uma criança mais clara ainda, fruto de um casamento com um homem branco. Esse ideal de branqueamento não se deu apenas no Brasil, como mostram os artistas da época. Em Cuba, por exemplo, há representação visual semelhante, na obra Las cuatro geraciones, de Víctor Patrício Landaluze, que se encontra no Museo Nacional de Bellas Artes de Cuba, evidenciando-se que o embranquecimento foi um ideal imposto em virtude de uma colonização que impunha aos "outros" sujeitos, indígenas e negros, a marca da diferença, da inferioridade.

\section{CONSIDERAÇÕES FINAIS}

Para Frantz Fanon (2008), o negro não deve mais ser colocado diante desse dilema: branquear ou desaparecer, podendo tomar consciência de uma nova possibilidade de existir, ou ainda, se a sociedade lhe cria dificuldades por causa de sua cor, se encontra em seus sonhos a expressão de um desejo inconsciente de mudar de cor, o objetivo não será dissuadi-lo, aconselhando-o a "manter as distâncias"; ao contrário, o objetivo será, uma vez definidas as causas, torná-lo capaz de escolher a ação (ou a passividade) a respeito da verdadeira origem do conflito, isto é, as estruturas sociais.

\footnotetext{
${ }^{5}$ A obra fez parte da exposição Das galés às galerias: representações e protagonismos dos negros no acervo do Museu Nacional de Belas Artes, durante o ano de 2018, e faz parte do acerto permanente do mesmo museu.
} 
Já Abdias do Nascimento (1980) assevera que, não em vão, a população negra tem sido forçado a esquecer a sua História e sua condição por um tempo demasiadamente longo, sendo obrigada a ficar quieta, silenciada, e tendo que perdoar ou esquecer o holocausto de milhões de africanos friamente assassinados, torturados, estuprados e raptados por criminosos europeus durante a escravidão e depois dela; o povo negro, em atitude de consciência, deve clamar e reclamar, não cooperando com os escravocratas de ontem e de hoje, que pregam que a escravidão foi um "passo necessário" ao desenvolvimento do ocidente.

De forma contrária, a escravidão foi um passo para trás na história, pois condenou homens e mulheres a uma condição de subcidadania, enquanto elevou outros à condição de privilégios, os quais necessitam ser objeto de tomada de consciência.

Nesse contexto, a consciência africana não pode ser abandonada. Elementos religiosos e culturais costumam reavivar essa consciência: esse voltar à África e reconhecer o ser negado no processo de colonização. Há um momento que esse momento de descida à consciência do próprio ser é escurecido/evidenciado ${ }^{6}$. Veja-se o pensamento de Damião:

E mais uma vez reconheceu que, a despeito do muito que vivera e também do muito lera e meditara, aqueles tambores tinham ainda o dom de lhe descer às raízes da consciência, para lhe dar de novo o mundo mágico de seus antepassados africanos, como se por eles falassem os voduns primitivos, princípio e essência de todas as coisas (MONTELLO, 2005, p. 655).

Essa consciência não pode ser apenas no sentido de se lutar contra o poder, pois este está aí formado e alicerçado em estruturas, mas de transformá-lo, inserindo a participação da população afro-brasileira em todos os degraus do poder como um imperativo de sua sobrevivência coletiva, como um povo, como um projeto de uma Nação inclusiva (NASCIMENTO, 1980).

Evidentemente, uma possível tomada do poder pelos negros foi sempre um pesadelo a perturbar o sono tranquilo das classes dominantes e governantes do Brasil, durante todo o decorrer de nossa história; não em vão se tornou um aspecto básico na

\footnotetext{
${ }^{6} \mathrm{O}$ racismo linguístico fez com que a palavra "esclarecer" se tornasse sinônimo de evidência, enquanto "obscurecer" de ignorância. Hoje, tenta-se contrapor tal jogo de subordinação linguística e restituir a evidência que a pretitude causa nas coisas. Nada evidencia mais um texto do que um negrito em uma frase ou um contorno preto em uma pintura.
} 
concepção de uma técnica e de uma estratégia para o esmagamento e desaparecimento completo do negro do mapa demográfico (NASCIMENTO, 1980).

Nesse sentido, deve-se oportunizar que, finalmente, a população brasileira desperte para a consciência de sua negritude. Um sinal dessa tomada de consciência é evidenciado quando, nos últimos anos, a maioria passa a se declarar negra e parda e questionar, por que esse projeto de Nação excluiu a população negra das zonas do saber, do poder e do ser.

A luta da população negra, como reconhecida no romance Os Tambores de São Luís não iniciou hoje e ainda exigirá muitos esforços e paciência. A recuperação da sua História, em uma trama que privilegiou o elemento branco, é fundamental, havendo uma necessidade urgente da população negra brasileira recuperar a sua memória, que tem sido agredida sistematicamente pela estrutura de poder e dominação, que causa graves distorções ao negar seu passado histórico (NASCIMENTO, 1980).

Nesse sentido, a recuperação da memória mocambeira e quilombola, como evidenciada no romance, é um importante passo, pois a contínua repetição do tratamento dado pelos brancos aos negros no passado, sem enfatizar suas realizações criativas e sua participação na construção da Nação, é outra maneira de discriminação (NASCIMENTO, 1980).

A representatividade negra na literatura, em um romance da dimensão como $O s$ Tambores de São Luís é muito significativa, pois o discurso das personagens é permeado pela tomada de consciência racial e pela exaltação das lutas da população negra pelos direitos à liberdade e à igualdade. Por outro lado, o fato de ter sido um homem branco o escritor da obra, oportuniza a reflexão quanto à necessidade de resgate de autoras e autores negros(as) que foram e são silenciados por aquilo que se denomina de epistemicídio, sintetizado da seguinte forma:

Nas Américas, os africanos eram proibidos de pensar, rezar ou de praticar suas cosmologias, conhecimentos e visão de mundo. Estavam submetidos a um regime de racismo epistêmico que proibia a produção autônoma de conhecimento. A inferioridade epistêmica foi um argumento crucial, utilizado para proclamar uma inferioridade social biológica, abaixo da linha da humanidade. A ideia racista preponderante no século XVI era a de 'falta de inteligência' dos negros, expressa no século XX como 'os negros apresentam o mais baixo coeficiente de inteligência’ (GROSFOGUEL, 2016, p. 40). 
Nesse contexto, como o romance trata de um discurso produzido a partir das estruturas hegemônicas, autor branco, que foi membro e presidente da Academia Brasileira de Letras - ABL, pode ser usado como instrumento de luta antirracista naquele ambiente e em outros lugares que têm repulsa em ouvir discursos de subalternidade, a fim de promover sensibilização e mobilização.

As respostas não são fáceis, tampouco rápidas, enganando-se quem pensa que o projeto implantado pelo colonialismo será derrubado a partir de um choque direto ou apenas com o discurso do não reconhecimento e da exclusão, apesar disso ser fundamental, principalmente, quando se discute tal problemática na zona do ser, desmascarando todas as formas de racismo. A criação de fissuras nessa superestrutura social e jurídica requer que haja a infiltração da população negra nos centros de dominação do saber (universidades etc.), poder (estruturas do legislativo, executivo, judiciário etc.) e do ser (todas as estruturas formais e informais que levem ao reconhecimento e inclusão do negro).

\section{REFERÊNCIAS BIBLIOGRÁFICAS}

ARAÚJO, Maria Raymunda [Mundinha]. Insurreição de Escravos em Viana -1867. São Luís: 2014.

AZEVEDO, Aluísio. O Mulato. Introdução e notas de Jomar Moraes e Sebastião Moreira Duarte. 2. ed. maranhense, evocativa do centenário da morte do autor. São Luís: Edições da Academia Maranhense de Letras - AML/Secretaria de Educação, 2013.

AZEVÊDO, Ariston. A sociologia antropocêntrica de Alberto Guerreiro Ramos. Tese (Doutorado em Sociologia Política), Universidade Federal de Santa Catarina - UFSC, Florianópolis, 2006, $355 \mathrm{f}$.

BELFORT, Conceição. A construção de uma identidade nacional na obra "Os tambores de São Luís”, de Josué Montello. Littera Online, v. 04, n. 06, São Luís, p. 1-13, 2013.

CARNEIRO, Sueli Aparecida. A construção do outro como não-ser como fundamento do ser. Tese (Doutorado em Educação), Universidade de São Paulo - USP, São Paulo, 2005, 339 f.

CRUZ, Leonardo Borges da. A formação discursiva pós-colonial em Alberto Guerreiro Ramos. Revista da ABPN: Associação Brasileiras de Pesquisadores Negros, v. 10, n. 25, mar./jun, p. 141164, 2018.

DUSSEL, Enrique. Política da libertação: história mundial e crítica. Trad. de Paulo César Carbonari. Passo Fundo: IFIBE, 2014. 
FANON, Frantz. Os condenados da Terra. Trad. de José Laurênio de Melo. Rio de Janeiro: Civilização Brasileira, 1968.

$\overline{2008 .}$ . Pele negra, máscaras brancas. Trad. de Renato da Silveira. Salvador: EDUFBA,

GILROY, Paul. O Atlântico Negro: modernidade e dupla consciência. Trad. de Cid Knipel Moreira. São Paulo/Rio de Janeiro: Editora 34/Universidade Cândido Mendes, 2001.

GOMES, Flávio dos Santos. Mocambos e quilombos: uma história do campesinato negro no Brasil. São Paulo: Claro Enigma, 2015.

GORDON, Lewis. Introdução. In: FANON, Frantz. Pele negra, máscaras brancas. Trad. de Renato da Silveira. Salvador: EDUFBA, 2008.

GROSFOGUEL, Ramón. A estrutura do conhecimento nas universidades ocidentalizadas: racismo/sexismo epistêmico e os quatro genocídios/epistemicídios do longo século XVI. In: Sociedade e Estado, v. 31, n.1, p. 25-49, 2016.

GRISSANT, Édouard. O quarto século. Trad. de Cleone Augusto Rodrigues. Rio de Janeiro: Editora Guanabara, 1986.

MALDONADO-TORRES, Nelson. Analítica da decolonialidade: algumas dimensões básicas. In: BERNARDINO-COSTA, Joaze et al. (org.). Pensamento Afro-diaspórico e decolonialidade. 2. ed. Belo Horizonte: Autêntica, 2019, p. 27-53.

MONTELLO, Josué. Os Tambores de São Luís: a saga do negro brasileiro. 1. ed. especial. Rio de Janeiro: Nova Fronteira, 2005.

MOURA, Clóvis. Os quilombos e a rebelião negra. São Paulo: Brasiliense, 1981.

NASCIMENTO, Abdias do. Quilombismo: um conceito científico emergente do processo histórico-cultural das massas afro-brasileiras. In: NASCIMENTO, Abdias do. O quilombismo: documentos de uma militância pan-africana. Petrópolis: Vozes, 1980, p. 245-281.

RAMOS, Alberto Guerreiro. Patologias social do "branco" brasileiro. In: RAMOS, Alberto Guerreiro. Introdução crítica à Sociologia brasileira. Rio de Janeiro: Editora UFRJ, 1995, p. 215240.

REIS, Maria Firmina dos. Úrsula. 2.ed. maranhense, evocativa do centenário da morte da autora. São Luís: Edições da Academia Maranhense de Letras - AML, 2017.

RODNEY, Walter. Como a Europa subdesenvolveu a África. Trad. de Edgar Valles. Lisboa: Serra Nova, 1975.

SANTOS, Joel Rufino dos. Saber do negro. Rio de Janeiro: Pallas, 2015.

SIQUEIRA, José Jorge. Pós-Abolição, intelectuais negros e projeto de Brasil: notas de um estudo. Revista da ABPN: Associação Brasileira de Pesquisadoras(es) Negras(os), Uberlândia, v. 10, n. 25, p. 82-100, mar./jun. 2018.

SOUSA, Meridalva Gonçalves de. História e ficção: a representação do negro escravizado e liberto no Maranhão do século XIX, na obra Os Tambores de São Luís, de Josué Montello. São Luís: Editora UEMA, 2015. 
ZAPATA OLIVELLA, Manuel. Changó, el gran putas. Bogotá: Ministerio de Cultura, 2010.

Recebido em: 15/05/2020

Aceito em 30/09/2020 